\title{
Coffee waste as an eco-friendly and low-cost alternative for biochar production impacts on sandy soil chemical attributes and microbial gene abundance
}

\author{
Cintia Caroline Gouveia da Silva ${ }^{1}$ (D), Erika Valente de Medeiros²,* (D), Giselle Gomes Monteiro \\ Fracetto $^{1}$ (D), Felipe José Cury Fracetto ${ }^{1}$ iD, Argemiro Pereira Martins Filho ${ }^{3}$ (D), José Romualdo de \\ Sousa Lima² (D), Gustavo Pereira Duda² (D), Diogo Paes da Costa² (iD, Mário Andrade Lira Junior ${ }^{1}$ (D), \\ Claude Hammecker ${ }^{4}$ iD \\ 1. Universidade Federal Rural de Pernambuco - Departamento de Agronomia - Recife (PE), Brazil. \\ 2. Universidade Federal do Agreste de Pernambuco - Laboratório de Enzimologia e Microbiologia Ambiental e Agrícola - Garanhuns (PE), Brazil. \\ 3. Universidade Federal de Viçosa - Departamento de Fitotecnia - Viçosa (MG), Brazil. \\ 4. Institut de Recherche pour le Développement - Montpellier, Provence-Alpes-Côte d'Azur - France.
}

Received: Oct. 30, 2020 | Accepted: Feb. 4, 2021

Section Editor: Hector Valenzuela

*Corresponding author: erika.valente@ufape.edu.br

How to cite: Silva, C. C. G., Medeiros, E. V., Fracetto, G. G. M., Fracetto, F. J. C., Martins Filho, A. P., Lima, J. R. S., Duda, G. P., Costa, D. P., Lira Júnior, M. A., Hammecker, C. (2021). Coffee waste as an eco-friendly and low-cost alternative for biochar production impacts on sandy soil chemical attributes and microbial gene abundance. Bragantia, 80, e2121. https://doi.org/10.1590/1678-4499.20200459

\begin{abstract}
Biochar is a material produced by the pyrolysis of agro-industrial waste, which has become one of the most promising management tools to improve soil quality. The aim was to determine the effects of incorporating biochar from different coffee wastes in sandy soil, cropped with maize, on soil chemical and microbial attributes. The experiment followed a factorial design $2 \times 3+1$ with two types of biochar, including coffee ground (CG) or coffee husk $(\mathrm{CH})$ in 3 doses $\left(4,8\right.$, and $\left.16 \mathrm{t} \cdot \mathrm{ha}^{-1}\right)$ and a control fertilized solely with bovine manure $\left(3 \mathrm{t} \cdot h \mathrm{a}^{-1}\right)$. The variables analyzed were soil organic carbon, chemical attributes, microbial biomass ( $\mathrm{C}, \mathrm{N}$ and $\mathrm{P}$ ), soil basal respiration and microbial gene abundance (16S rRNA, 18S rRNA and nifH gene). Most chemical attributes were strongly increased by $\mathrm{CH}$ application, while $\mathrm{CG}$ at $8 \mathrm{t} \cdot \mathrm{ha}^{-1}$ increased the soil $\mathrm{C}: \mathrm{N}$ ratio (3.5 times), $\mathrm{P}$ (2.1 times) and $\mathrm{K}+$ (7.9 times) and at $4 \mathrm{t} \cdot \mathrm{ha}^{-1}$ increased the $\mathrm{C}$ content, microbial biomass $\mathrm{C}$ and $\mathrm{N}\left(3,2.1\right.$ and 1.6 times, respectively). The application of CG biochar at $16 \mathrm{t} \cdot \mathrm{ha}^{-1}$ showed trend to increase the abundance of bacteria, fungi and diazotrophic genes ( 11,10 and $2 \%$, respectively). Contribution of both coffee biochar types, but mainly $\mathrm{CH}$, was more effective than the soil that received organic manure alone. Biochar from coffee wastes is a promising tool to improve sandy soil quality.
\end{abstract}

Key words: biocarbon, 16S rRNA, 18S rRNA, nifH.

\section{INTRODUCTION}

Excessive application of chemical fertilizers for improved plant growth and yield has become a serious problem around the world due to excessive losses to the environment leading to both eutrophication of water bodies and greenhouse gas emissions. On the other hand, intensive agriculture depletes soil nutrients, which must be furnished by the farmer. Therefore, there has been an increasing search for alternatives that reuse more waste, are accessible to producers and are environmentally friendly, such as biochar (Liu et al. 2018).

More than 200 million tons of biomass from agro-industry wastes are not exploited in Brazil and its usage would be advantageous (Martinez et al. 2019). Thus, biochar may serve as an economic alternative to producers by reducing dependence on chemical fertilizers, as well as reusing agro-industrial waste with potential applicability on several crops (Lima et al. 2018). Biochar is a carbonaceous-rich material produced from biomass waste by pyrolysis with a wide temperature range between 100 and $700{ }^{\circ} \mathrm{C}$ (Rangabhashiyam and Balasubramanian 2019). 
The addition of biochar from different sources to acid soils improve soil quality and plant growth due to the alkalinity to neutralize soil acidity and a high $\mathrm{pH}$ buffering capacity (especially when pyrolyzed at high temperatures). $\mathrm{Al}^{3+} \mathrm{can}$ be precipitated to less toxic compounds with the alkaline oxides, carbonates and silicates in biochar. The biochar shift in $\mathrm{pH}$ and the reduction in $\mathrm{Al}$ caused by biochar improves the availability of $\mathrm{P}, \mathrm{Ca}$ and $\mathrm{Mg}$, resulting in a balanced nutrient supply in the rhizosphere, thus enhancing the productivity of cultivated plants (Yu et al. 2019).

The application of biochar from different residues improves soil quality and crop performance, increasing carbon sequestration (Tan et al. 2017), soil porosity, soil aggregate stability, the activity of beneficial microorganisms and soil fertility (Pranagal et al. 2017). The improvements promoted by biochar on the chemical and physical attributes of the soil contribute to increase the microbial activity, carbon, nitrogen and phosphorus contents of nutrient cycling and increases the microbial colonization rate, since the pores of the biochar serve as habitat for microorganisms and protect against attack by predators (Singh et al. 2018). Some studies have also shown that biochar applied to the soil at different doses increase fungi, bacteria and microorganism populations involved with nitrogen cycling (Liu et al. 2019; Semida et al. 2019; Medeiros et al., 2021). For example, some remarkable increases in copy numbers or specific gene diversity were reported, leading to modifications in the composition and abundance of a microbial community (Zheng et al. 2016).

One possible agro-industrial residue for biochar production is the coffee industry, which has a wide availability of both grain and husk wastes with low cost and high nutrient content (Tsai et al. 2012; Lima et al. 2018). However, this possible reuse as biochar feed material is not yet known, as well as its impact on sandy soils.

This study evaluated the reuse of agro-industrial wastes and application of two biochar types from coffee (Coffea arabica) on sandy soil. The objectives of the present study were to demonstrate the impact of two types of biochar and cow manure applied to sandy soil on soil quality, specially examining 1) soil chemical attributes; 2) microbial biomass carbon, nitrogen and phosphorus (MBC, Nmic and Pmic); 3) soil basal respiration (SBR) and metabolic quotient $\left(q \mathrm{CO}_{2}\right)$; and 4) microbial gene abundance (16S rRNA, $18 \mathrm{~S}$ rRNA and nifH).

\section{MATERIAL AND METHODS}

\section{Soil collection and characterization}

The soil used in the experiment was collected from the $0-20 \mathrm{~cm}$ layer of a native Brazilian tropical dry sub-humid forest of Pernambuco (latitude $8^{\circ} 48^{\prime} 34.2^{\prime \prime}$ S, longitude $36^{\circ} 24^{\prime} 29.3^{\prime \prime} \mathrm{W}$ ) at $705 \mathrm{~m}$ above mean sea level. According to the Köppen classification system, the climate in the region is hot and humid ('As'). The mean total annual rainfall is $782 \mathrm{~mm}$ and the mean annual air temperature is $23.2^{\circ} \mathrm{C}$. The topography of the area is flat to smooth-wavy. Its original vegetation cover was Caatinga, which is a tropical deciduous forest, with Fabaceae, Euphorbiaceae and Cactaceae (Barros et al. 2019) as the main genera. The soil is a lamellic eutric regosol, according to the classification system of the food and agriculture organization, with almost $90 \%$ sand and $<5 \%$ clay and it had $1.6 \%$ total C, $0.24 \%$ total N, $\mathrm{pH}$ of 5.1, extremely low values of cation exchange capacity (CEC) (3.98), specific surface area of 0.05 , total porosity of $0.433 \mathrm{~m}^{3} \cdot \mathrm{m}^{-3}$ and field capacity of $0.135 \mathrm{~m}^{3} \cdot \mathrm{m}^{-3}$. Its mineral composition was quartz (90\%), plagioclase and $\mathrm{K}$-feldspar (5\%), kaolinite, mica and traces of iron oxide (Lima et al. 2018).

\section{Biochar production and properties}

Two common agro-industrial wastes (coffee husk $[\mathrm{CH}]$ and coffee grounds [CG]) from the coffee industry were used as biochar feedstock. Both were charred during 10 to $12 \mathrm{~h}$ under oxygen limited conditions in a slow pyrolysis process where temperature reached $530{ }^{\circ} \mathrm{C}$. The final $\mathrm{CH}$ biochar contained $67.11 \%$ total $\mathrm{C}, 2.05 \%$ total $\mathrm{N}$ and had a $\mathrm{pH}$ of 10.31 , CEC of 22.54, specific surface area (SSA) of 244, while the final CG biochar contained 
$68.81 \%$ total C, $4.30 \%$ total $\mathrm{N}$ and had a $\mathrm{pH}$ of 9.65, CEC of 5.56, SSA of 23.5. Other important biochar properties are listed in Lima et al (2018).

\section{Experiment design}

The experimental design was completely randomized, distributed in a factorial scheme $(2 \times 3+1)$ with two types of biochar ( $\mathrm{CH}$ and $\mathrm{CG})$ in 3 doses (4, 8 and $\left.16 \mathrm{t} \cdot \mathrm{ha}^{-1}\right)$ and one additional treatment without biochar, with 10 repetitions. Pot experiments were performed in a greenhouse in Garanhuns, Pernambuco, Brazil (0853'25”S and 36²9’34”W) with an elevation of $896 \mathrm{~m}$ and mesothermal tropical altitude (Cs'a) climate, according to Köppen, with annual average temperature and precipitation of $20^{\circ} \mathrm{C}$ and $1,300 \mathrm{~mm}$, respectively (Lima et al. 2018). All pots of $4 \mathrm{~L}$ ( $0.19 \mathrm{~m}$ of diameter at the top, $0.13 \mathrm{~m}$ diameter at the bottom and $0.15 \mathrm{~m}$ high) received $3 \mathrm{t} \cdot \mathrm{ha}^{-1}$ of bovine manure. Phosphorus and potassium fertilization were carried out on the day of planting, nitrogen was applied 21 days after planting in all pots. Phosphorus and potassium fertilization were carried out on the day of planting, nitrogen was applied 21 days after planting in all pots, according to IPA Recommendation (Cavalcanti 2008) of Pernambuco state (0.08 $\mathrm{g}$ of $\mathrm{N} ; 0.08 \mathrm{~g}$ of $\mathrm{P}$ and $0.06 \mathrm{~g}$ of $\mathrm{K} \mathrm{pot}^{-1}$ in the forms of urea, single superphosphate [SSP] and $\mathrm{KCl}$ ). Four seeds of maize cultivar 1058 frequently used in the region were seeded per $5 \mathrm{~kg}$ pot and thinned to one plant per pot a week after emergence. The pots were irrigated every two days with distilled water to maintain soil at field capacity. After 45 days of sowing, the soil samples were collected for chemical and microbiological analysis and one part was stored in $2 \mathrm{~mL}$ microtubes inside the freezer for molecular analyses at $-20^{\circ} \mathrm{C}$. The mixture of five subsamples formed a composite sample in each pot that was considered an experimental plot.

\section{Soil chemical and microbiological attributes}

Samples were air-dried, homogenized and sieved at $2 \mathrm{~mm}$ mesh screen. Soil chemical attributes were measured according to Silva (2009), with $\mathrm{Ca}^{2+}, \mathrm{Mg}^{2+}, \mathrm{Al}^{3+}$ extracted by $\mathrm{KCl}$ at $1.0 \mathrm{~mol} \cdot \mathrm{L}^{-1}$ and $\mathrm{K}^{+}, \mathrm{Na}^{+}, \mathrm{P}, \mathrm{by} \mathrm{Mehlich}^{-1}$. $\mathrm{Ca}^{2+}$ and $\mathrm{Mg}^{2+}$ were determined by atomic absorption spectrophotometry, $\mathrm{K}^{+}$and $\mathrm{Na}^{+}$were determined by flame photometry, while $\mathrm{P}$ by colorimetry and $\mathrm{Al}^{3+}$ by titration.

Total organic carbon (TOC) was determined according to Yeomans and Bremner (1988). From the results obtained, the bases sum (BS) and the CEC were calculated. Soil carbon (C) and nitrogen (N) contents were determined by combustion with an CHNS-O elemental analyzer (Perkin Elmer PE-2400).

Carbon microbial biomass, Nmic and Pmic were estimated by irradiation-extraction according to Mendonça and Matos (2017). Carbon and nitrogen microbial contents were extracted with $0.5 \mathrm{~mol} \cdot \mathrm{L}^{-1}$ of potassium sulfate $\left(\mathrm{K}_{2} \mathrm{SO}_{4}\right)$, $80 \mathrm{~mL}$ per sample, with $\mathrm{pH}$ adjusted to $6.5-6.8$ and $\mathrm{P}$ was extracted with $0.5 \mathrm{~mol} \cdot \mathrm{L}^{-1}$ sodium bicarbonate $\left(\mathrm{NaHCO}_{3}\right)$. Soil basal respiration was quantified according to Alef and Nannipieri (1995) and the $q \mathrm{CO}_{2}$ was calculated according to Anderson and Domsch (1993) as the relation between SBR and MBC.

Total genomic DNA was extracted from $0.5 \mathrm{~g}$ freeze-dried soil of each sample using a PureLink microbiome DNA purification kit (Life Technologies, Carlsbad, USA) according to the manufacturer instructions. The purity and integrity of extracted DNA were detected by $1 \%$ agarose gel electrophoresis at $100 \mathrm{~V}$ for $30 \mathrm{~min}$ in $0.5 \times$ TBE buffer (Tris, Borate, EDTA) added to the SYBR Gold dye (Invitrogen, Breda, Netherlands). The DNA concentration was determined by fluorometry using a Qubit fluorometer (Life Technologies, USA) and the Quant-iT dsDNA BR kit (Life Technologies, USA). The extracted genomic DNA was stored at $-20^{\circ} \mathrm{C}$ for later use.

Total abundance of bacteria (16S rRNA gene), fungi (18S rRNA gene) and diazotrophs (nifH gene) were quantified by real-time polymerase chain reaction (qPCR). The quantifications were performed with a LightCycler 480 (Roche Applied Science), using the SYBR green I system. The reactions for the respective genes were performed in a $10 \mu \mathrm{L}$ volume containing $5 \mu \mathrm{L}$ Platinum Quantitative PCR SuperMix-UDG (Life Technologies - Invitrogen, Grand Island, NY, USA), $10 \mu \mathrm{mol} \cdot \mathrm{L}^{-1}$ of the specific primers for each gene and $1 \mu \mathrm{L}$ of DNA. Detailed information on the qPCR reaction procedures, primers and reaction conditions are described in Table 1. 
Table 1. Primers and cycling conditions used to amplify the target genes.

\begin{tabular}{|c|c|c|}
\hline \multirow[t]{2}{*}{ Primers PCR-DGGE } & Primer sequence (5'-3') & \multirow[t]{2}{*}{ Thermal cycling conditions } \\
\hline & Total bacteria (16S rRNA) & \\
\hline $341 f-G C^{1}$ & $\begin{array}{l}\text { CGCCCGCCGCGCGCGGCGGGCGGGGCGGGG } \\
\text { GCACGGGGGGCCTACGGGAGGCAGCAG }\end{array}$ & \multirow{2}{*}{$\begin{array}{c}95^{\circ} \mathrm{C} 10 \mathrm{~min}, 1 \text { cycle; } 95^{\circ} \mathrm{C} 1 \mathrm{~min}, 57^{\circ} \mathrm{C} 1 \\
\min , 72^{\circ} \mathrm{C} 3 \text { min, } 30 \text { cycles; } 72^{\circ} \mathrm{C} 10 \mathrm{~min}, 1 \\
\text { cycle }\end{array}$} \\
\hline $518 r^{1}$ & ATTACCGCGGCTGCTGG & \\
\hline \multicolumn{3}{|c|}{ Total fungi (18S rRNA) } \\
\hline $\mathrm{EF}^{2}$ & AAGGG(G/A)TGTATTTATTAG & \multirow{2}{*}{$\begin{array}{l}94^{\circ} \mathrm{C} 5 \mathrm{~min}, 1 \text { cycle; } 94^{\circ} \mathrm{C} 1 \mathrm{~min}, 55^{\circ} \mathrm{C} 30 \mathrm{~s} \text {, } \\
72^{\circ} \mathrm{C} 90 \mathrm{~s}, 34 \text { cycles; } 72^{\circ} \mathrm{C} 5 \mathrm{~min}, 1 \text { cycle }\end{array}$} \\
\hline ITS4 $4^{3}$ & CAGGAGACTTCTACACGGTCCAG & \\
\hline ITS1f-GC ${ }^{4}$ & $\begin{array}{l}\text { CCCCCGCCGCGCGCGGCGGGCGGGGCGGGG } \\
\text { GCACGGGCCGCTTGGTCATTTAGAGGAAGTAA }\end{array}$ & \multirow{2}{*}{$\begin{array}{l}94^{\circ} \mathrm{C} 5 \mathrm{~min}, 1 \text { cycle; } 94^{\circ} \mathrm{C} 30 \mathrm{~s}, 55^{\circ} \mathrm{C} 30 \mathrm{~s} \text {, } \\
72^{\circ} \mathrm{C} 30 \mathrm{~s}, 34 \text { cycles; } 72^{\circ} \mathrm{C} 5 \mathrm{~min}, 1 \text { cycle }\end{array}$} \\
\hline ITS2 $2^{5}$ & GCTGCGTTCTTCATCGATGC & \\
\hline \multicolumn{3}{|c|}{$\mathrm{N}$-fixing bacteria (nifH) } \\
\hline FGPH196 & TACGGCAARGGTGGNATH & \multirow{2}{*}{$\begin{array}{l}95^{\circ} \mathrm{C} 5 \mathrm{~min}, 1 \text { cycle; } 95^{\circ} \mathrm{C} 1 \mathrm{~min}, 55^{\circ} \mathrm{C} 1 \mathrm{~min} \text {, } \\
72^{\circ} \mathrm{C} 2 \mathrm{~min}, 30 \text { cycles; } 72^{\circ} \mathrm{C} 10 \mathrm{~min}, 1 \mathrm{cycle}\end{array}$} \\
\hline PolR $^{7}$ & ATSGCCATCATYTCRCCG & \\
\hline PolF-GC ${ }^{7}$ & $\begin{array}{l}\text { CGCCCGCCGCGCCCCGCGCCCGGCCCGCCG } \\
\text { CCCCCGCCCCTCCGAYCCSAARGCBGACTC }\end{array}$ & \multirow{2}{*}{$\begin{array}{l}94^{\circ} \mathrm{C} 5 \mathrm{~min}, 1 \text { cycle; } 95^{\circ} \mathrm{C} 1 \mathrm{~min}, 48^{\circ} \mathrm{C} 1 \mathrm{~min} \text {, } \\
72^{\circ} \mathrm{C} 2 \mathrm{~min}, 30 \text { cycles; } 72^{\circ} \mathrm{C} 10 \mathrm{~min}, 1 \text { cycle }\end{array}$} \\
\hline AQER $^{7}$ & ACTATGTAGATYTCCTG & \\
\hline \multirow[t]{2}{*}{ Primers qPCR } & Primer sequence (5'-3') & \multirow[t]{2}{*}{ Thermal cycling conditions } \\
\hline & Total bacteria (16S rRNA) & \\
\hline $341 f^{1}$ & CCTACGGGAGGCAGCAG & \multirow{2}{*}{$\begin{array}{c}95^{\circ} \mathrm{C} 5 \mathrm{~min}, 1 \text { cycle; } 95^{\circ} \mathrm{C} 10 \mathrm{~s}, 60^{\circ} \mathrm{C} 10 \mathrm{~s} \\
72^{\circ} \mathrm{C} 30 \mathrm{~s}, 40 \text { cycles }\end{array}$} \\
\hline $518 r^{1}$ & ATTACCGCGGCTGCTGG & \\
\hline \multicolumn{3}{|c|}{ Total fungi (18S rRNA) } \\
\hline ITS1f $^{8}$ & TCCGTAGGTGAACCTGCGG & \multirow{2}{*}{$\begin{array}{c}95^{\circ} \mathrm{C} 15 \mathrm{~min}, 1 \text { cycle; } 95^{\circ} \mathrm{C} 1 \mathrm{~min}, 53^{\circ} \mathrm{C} 30 \mathrm{~s} \text {, } \\
72^{\circ} \mathrm{C} 1 \mathrm{~min}, 40 \text { cycles }\end{array}$} \\
\hline $5.8 S^{8}$ & CGCTGCGTTCTTCATCG & \\
\hline \multicolumn{3}{|c|}{$\mathrm{N}$-fixing bacteria (nifH) } \\
\hline FGPH196 & TACGGCAARGGTGGNATH & \multirow{2}{*}{$\begin{array}{l}95^{\circ} \mathrm{C} 5 \mathrm{~min}, 1 \text { cycle; } 94^{\circ} \mathrm{C} 1 \mathrm{~min}, 57^{\circ} \mathrm{C} 45 \mathrm{~s} \text {, } \\
72^{\circ} \mathrm{C} 1 \mathrm{~min}, 30 \text { cycles; } 72^{\circ} \mathrm{C} 7 \mathrm{~min}, 1 \text { cycle }\end{array}$} \\
\hline PolR ${ }^{7}$ & ATSGCCATCATYTCRCCG & \\
\hline
\end{tabular}

${ }^{1}$ Muyzer et al. (1993); ${ }^{2}$ Smit et al. (1999); ${ }^{3}$ White et al. (1990); ${ }^{4}$ Gardes and Bruns (1993); ${ }^{5}$ Anderson et al. (2003); ${ }^{6}$ Simonet et al. (1991); ${ }^{7}$ Poly et al. (2001); ${ }^{8}$ Fierer et al. (2005).

The polymerase chain reaction-denaturing gradient gel electrophoresis (PCR-DGGE) profiles were performed using a vertical D-code system (Bio-Rad Laboratories, USA). The 8\% DGGE polyacrylamide gels were prepared with a denaturing gradient of 15 to $55 \%$ for $16 \mathrm{~S}$ rRNA, 20 to $55 \%$ for nif $\mathrm{H}$ and 30 to $45 \%$ for $18 \mathrm{~S}$ rRNA. Denaturation of $100 \%$ consisted of the concentration of $7 \mathrm{M}$ urea and $40 \%$ formamide. The gels for total bacteria and nif $\mathrm{H}$ were electrophoresed for $3 \mathrm{~h}$ at $200 \mathrm{~V}$ at $60{ }^{\circ} \mathrm{C}$, while for total fungi, the gels were electrophoresed for $16 \mathrm{~h}$ at $100 \mathrm{~V}$. After electrophoresis, the gels were stained with SYBR Gold (Invitrogen, Breda, The Netherlands) in $0.5 \times$ TAE (Tris, acetate, EDTA) in the dark for $40 \mathrm{~min}$ and photographed under ultraviolet light using an E-BOX VX2 UV transilluminator. The gels were evaluated using the Gel Analyzer 2010 program. The structural similarity of the bacteria, fungi and diazotrophs communities was determined based on the presence or absence of amplicons detected after DGGE.

\section{Statistical analysis}

All statistical and exploratory analyzes were performed on the R language (build version 3.4.3, R Core Team (2020)).

Data were submitted to normality test, using the Shapiro-Wilk statistic, analysis of variance and, when appropriate, the means compared by Tukey's test at $5 \%$ of significance, while orthogonal contrasts were made between the factorial 
treatments and the control. Dunnett's test at the 5\% significance level was also used to compare the control with each biochar treatment. Canonical analysis of principal coordinates (CAP) ordination was calculated through the "vegan" library, a useful method of constrained ordination for ecology (Anderson et al. 2003). Biplot graphics were made through the ggplot2 library and the heatmaps graphics were built with the heatmaply library with correlations calculated by the Pearson coefficient for parametric data.

\section{RESULTS AND DISCUSSION}

\section{Characterization of biochar and soil chemical attributes}

The characterization of the different biochars ( $\mathrm{pH}, \mathrm{P}, \mathrm{Ca}, \mathrm{Mg}, \mathrm{K}, \mathrm{Al}, \mathrm{Na}$, cation exchange capacity, $\mathrm{C}, \mathrm{N}$, specific surface area, phosphorus adsorption isotherm, field capacity and wilting point) are shown in a previous paper (Lima et al. 2018). In summary, biochar soil mixtures properties were significantly affected by type of coffee waste and dose used (Table 2).

Table 2. Chemical attributes in a sandy soil that received different doses of biochar from CG and $\mathrm{CH}$, cultivated with maize.

\begin{tabular}{|c|c|c|c|c|c|c|c|c|c|c|}
\hline & \multicolumn{10}{|c|}{$\mathrm{pH}^{(1)}$} \\
\hline & $4 \mathrm{t} \cdot \mathrm{ha}^{-1}$ & & $8 \mathrm{t} \cdot \mathrm{ha}^{-1}$ & & $16 \mathrm{t} \cdot \mathrm{h} \mathrm{a}^{-1}$ & & Mean & & Model $^{(4)}$ & $\mathbf{R}^{2}$ \\
\hline CG & $5.02^{(2)}$ & $b$ & 5.08 & $b$ & 5.27 & a & 5.12 & & $f(x)=5.12$ & ns \\
\hline $\mathrm{CH}$ & 5.62 & $\mathrm{aB}$ & 6.04 & $\mathrm{aA}$ & 5.17 & $\mathrm{aAB}$ & 5.61 & & $f(x)=0.047 x+6.05$ & 0.45 \\
\hline Mean & 5.32 & & 5.56 & & 5.22 & & 5.37 & (3) & & \\
\hline \multirow[t]{3}{*}{ Control } & & & & & & & 4.43 & & & \\
\hline & \multicolumn{10}{|c|}{$N\left(\mathbf{g} \cdot \mathbf{k g}^{-1}\right)$} \\
\hline & $4 \mathrm{t} \cdot \mathrm{ha}^{-1}$ & & $8 \mathrm{t} \cdot \mathrm{ha}^{-1}$ & & $16 \mathrm{t} \cdot h \mathrm{a}^{-1}$ & & Mean & & Model & $\mathbf{R}^{2}$ \\
\hline CG & $40.95^{(4)}$ & & 16.82 & & 26.17 & & 27.98 & a & $f(x)=27.98$ & ns \\
\hline $\mathrm{CH}$ & 33.91 & & 69.06 & & 38.85 & & 47.27 & a & $f(x)=47.27$ & ns \\
\hline Mean & 37.43 & & 42.94 & & 32.51 & & 37.63 & & & \\
\hline \multirow[t]{3}{*}{ Control } & & & & & & & 42.39 & & & \\
\hline & \multicolumn{10}{|c|}{$C\left(\mathbf{g} \cdot \mathbf{k g}^{-1}\right)$} \\
\hline & $4 \mathrm{t} \cdot \mathrm{ha}^{-1}$ & & $8 \mathrm{t} \cdot h \mathrm{a}^{-1}$ & & $16 \mathrm{t} \cdot \mathrm{ha} \mathrm{a}^{-1}$ & & Mean & & Model & $\mathbf{R}^{2}$ \\
\hline CG & 82.02 & & 83.86 & & 76.57 & & 80.82 & $b$ & $f(x)=80.82$ & ns \\
\hline $\mathrm{CH}$ & 153.10 & & 122.13 & & 122.15 & & 132.46 & a & $f(x)=132.46$ & ns \\
\hline Mean & 117.56 & & 103.00 & & 99.36 & & 106.64 & & & \\
\hline Control & & & & & & & 51.08 & & & \\
\hline C:N ratio & $4 \mathrm{t} \cdot \mathrm{ha}^{-1}$ & & $8 \mathrm{t} \cdot \mathrm{ha}^{-1}$ & & $16 \mathrm{t} \cdot \mathrm{ha}^{-1}$ & & Mean & & Model & $\mathbf{R}^{2}$ \\
\hline CG & 2.55 & $b$ & 5.25 & a & 3.45 & a & 3.75 & & $f(x)=3.75$ & ns \\
\hline $\mathrm{CH}$ & 5.81 & a & 2.22 & $b$ & 3.22 & a & 3.75 & & $f(x)=3.75$ & ns \\
\hline Mean & 4.18 & & 3.74 & & 3.34 & & 3.75 & & & \\
\hline \multirow[t]{3}{*}{ Control } & & & & & & & 1.51 & & & \\
\hline & \multicolumn{10}{|c|}{$\mathrm{Na}^{+}\left(\mathrm{Cmol}_{\mathrm{c}} \cdot \mathrm{kg}^{-1} \cdot\right.$ soil $)$} \\
\hline & $4 \mathrm{t} \cdot \mathrm{ha}^{-1}$ & & $8 \mathrm{t} \cdot \mathrm{ha}^{-1}$ & & $16 \mathrm{t} \cdot \mathrm{ha}^{-1}$ & & Mean & & Model & $\mathbf{R}^{2}$ \\
\hline CG & 0.14 & a & 0.14 & a & 0.14 & a & 0.14 & & $f(x)=0.14$ & ns \\
\hline $\mathrm{CH}$ & 0.16 & a & 0.02 & $\mathrm{~b}$ & 0.13 & a & 0.10 & & $f(x)=0.10$ & ns \\
\hline Mean & 0.15 & & 0.08 & & 0.14 & & 0.12 & & & \\
\hline Control & & & & & & & 0.10 & & & \\
\hline
\end{tabular}


Table 2. Continuation...

\begin{tabular}{|c|c|c|c|c|c|c|c|c|c|c|}
\hline & \multicolumn{8}{|c|}{$\mathrm{K}^{+}\left(\mathrm{Cmol}_{\mathrm{c}} \cdot \mathrm{kg}^{-1} \cdot\right.$ soil $)$} & \multirow[b]{2}{*}{ Model } & \multirow[b]{2}{*}{$\mathbf{R}^{2}$} \\
\hline & $4 t \cdot h a^{-1}$ & & $8 \mathrm{t} \cdot \mathrm{ha}^{-1}$ & & $16 \mathrm{t} \cdot \mathrm{ha} \mathrm{a}^{-1}$ & & Mean & & & \\
\hline CG & 0.13 & B & 0.18 & $A B$ & 0.26 & $A$ & 0.19 & $b$ & $f(x)=0.011 x+0.086$ & 0.99 \\
\hline $\mathrm{CH}$ & 0.43 & & 0.63 & & 0.33 & & 0.46 & a & $f(x)=0.46$ & ns \\
\hline Mean & 0.28 & & 0.40 & & 0.30 & & 0.33 & & & \\
\hline \multirow[t]{3}{*}{ Control } & & & & & & & 0.08 & & & \\
\hline & \multicolumn{8}{|c|}{$P\left(\mathbf{m g} \cdot \mathbf{k g}^{-1}\right)$} & & \\
\hline & $4 \mathrm{t} \cdot h \mathrm{a}^{-1}$ & & $8 \mathrm{t} \cdot h \mathrm{a}^{-1}$ & & $16 \mathrm{t} \cdot \mathrm{ha}^{-1}$ & & Mean & & Model & $\mathbf{R}^{2}$ \\
\hline CG & 8.11 & a & 9.55 & $\mathrm{~b}$ & 10.21 & a & 9.29 & & $f(x)=9.29$ & ns \\
\hline $\mathrm{CH}$ & 8.04 & a & 15.25 & a & 7.13 & $\mathrm{~b}$ & 10.14 & & $f(x)=10.14$ & ns \\
\hline Mean & 8.08 & & 12.40 & & 8.67 & & 9.71 & A & & \\
\hline \multirow[t]{3}{*}{ Control } & & & & & & & 7.06 & B & & \\
\hline & \multicolumn{8}{|c|}{$\mathrm{H}^{+}+\mathrm{Al}^{3+}\left(\mathrm{Cmol}_{\mathrm{c}} \cdot \mathrm{kg}^{-1}\right)$} & & \\
\hline & $4 t \cdot h a^{-1}$ & & $8 \mathrm{t} \cdot \mathrm{ha}^{-1}$ & & $16 \mathrm{t} \cdot \mathrm{ha}^{-1}$ & & Mean & & Model & $\mathbf{R}^{2}$ \\
\hline CG & 3.93 & $\mathrm{aAB}$ & 4.21 & $\mathrm{aA}$ & 3.66 & bB & 3.93 & & $f(x)=-0.029 x+4.21$ & 0.43 \\
\hline $\mathrm{CH}$ & 3.88 & $\mathrm{aB}$ & 4.48 & $\mathrm{aA}$ & 4.32 & $\mathrm{aAB}$ & 4.23 & & $f(x)=0.028 x+3.96$ & 0.31 \\
\hline Mean & 3.91 & & 4.35 & & 3.99 & & 4.08 & & & \\
\hline \multirow[t]{3}{*}{ Control } & & & & & & & 4.37 & & & \\
\hline & \multicolumn{8}{|c|}{$\mathrm{Ca}^{2+}\left(\mathrm{Cmol}_{\mathrm{c}} \cdot \mathrm{kg}^{-1} \cdot\right.$ soil $)$} & & \\
\hline & $4 t \cdot h a^{-1}$ & & $8 \mathrm{t} \cdot \mathrm{ha}^{-1}$ & & $16 \mathrm{t} \cdot \mathrm{h} \mathrm{a}^{-1}$ & & Mean & & Model & $\mathbf{R}^{2}$ \\
\hline CG & 0.65 & & 0.79 & & 0.58 & & 0.67 & a & $f(x)=0.67$ & ns \\
\hline $\mathrm{CH}$ & 0.67 & & 0.72 & & 0.63 & & 0.67 & a & $f(x)=0.67$ & ns \\
\hline Mean & 0.66 & & 0.76 & & 0.60 & & 0.67 & & & \\
\hline \multirow[t]{3}{*}{ Control } & & & & & & & 0.62 & & & \\
\hline & \multicolumn{8}{|c|}{$\mathrm{Mg}_{2+}\left(\mathrm{Cmol}_{\mathrm{c}} \cdot \mathrm{kg}^{-1} \cdot\right.$ soil $)$} & & \\
\hline & $4 \mathrm{t} \cdot h \mathrm{a}^{-1}$ & & $8 \mathrm{t} \cdot h a^{-1}$ & & $16 \mathrm{t} \cdot \mathrm{ha}^{-1}$ & & Mean & & Model & $\mathbf{R}^{2}$ \\
\hline CG & 1.074 & & 1.067 & & 1.005 & & 1.049 & a & $f(x)=1.05$ & ns \\
\hline $\mathrm{CH}$ & 1.011 & & 1.073 & & 0.992 & & 1.026 & a & $f(x)=1.03$ & ns \\
\hline Mean & 1.043 & & 1.070 & & 0.999 & & 1.037 & A & & \\
\hline \multirow[t]{3}{*}{ Control } & & & & & & & 1.055 & A & & \\
\hline & \multicolumn{8}{|c|}{$\mathrm{Al}^{+}\left(\mathrm{Cmol}_{c} \cdot \mathrm{kg}^{-1} \cdot\right.$ soil $)$} & & \\
\hline & $4 t \cdot h a^{-1}$ & & $8 \mathrm{t} \cdot \mathrm{ha}^{-1}$ & & $16 \mathrm{t} \cdot \mathrm{ha}^{-1}$ & & Mean & & Model & $\mathbf{R}^{2}$ \\
\hline CG & 0.150 & a & 0.133 & a & 0.167 & a & 0.150 & & $f(x)=0.15$ & ns \\
\hline $\mathrm{CH}$ & 0.100 & $b$ & 0.083 & $b$ & 0.194 & a & 0.126 & & $f(x)=0.0087 x+0.044$ & 0.79 \\
\hline Mean & 0.125 & & 0.108 & & 0.181 & & 0.138 & & & \\
\hline \multirow[t]{3}{*}{ Control } & & & & & & & 0.217 & & & \\
\hline & \multicolumn{8}{|c|}{ TOC $\left(\mathbf{g} \cdot \mathbf{k g}^{-1}\right)$} & & \\
\hline & $4 \mathrm{t} \cdot \mathrm{ha}^{-1}$ & & $8 \mathrm{t} \cdot \mathrm{ha}^{-1}$ & & $16 \mathrm{t} \cdot \mathrm{ha}^{-1}$ & & Mean & & Model & $\mathbf{R}^{2}$ \\
\hline CG & 10.65 & & 11.30 & & 12.25 & & 11.40 & a & $f(x)=11.40$ & ns \\
\hline $\mathrm{CH}$ & 11.69 & & 10.94 & & 13.27 & & 11.96 & a & $f(x)=11.96$ & ns \\
\hline Mean & 11.17 & & 11.12 & & 12.76 & & 11.68 & & $f(x)=0.142 x+10.353$ & 0.87 \\
\hline Control & & & & & & & 10.11 & & & \\
\hline
\end{tabular}

(1) The analysis of variance was performed at the $5 \%$ significance level, where the absence of letters indicates that there were no significant differences (ns). Means followed by different lowercase letters between columns and uppercase letters between lines differed, using the Tukey's test at the $5 \%$ level of significance.

(2) The means in bold differed from the control according to the Dunnett test at the level of $5 \%$ of significance.

(3) Overall mean in bold differed from the control according to the Helmet's contrast at the $5 \%$ significance.

(4) Regression analysis was performed for the quantitative variables (increasing doses of the biochar) with different variances and the corresponding linear model $[f(x)]$ was shown for each biochar, followed by the adjusted $R^{2}$. In the case of data with equal variances (ns), the means were considered similar and the global mean (constant) was calculated. 
Soil pH, C, C:N, $\mathrm{Na}^{+}, \mathrm{K}^{+}, \mathrm{P}$ and TOC contents all increased with the application of biochar, while the $\mathrm{H}+\mathrm{Al}$ and $\mathrm{Al}^{3+}$ decreased, with higher values found for $\mathrm{CH}$ than for $\mathrm{CG}$ biochar (Table 2) for $\mathrm{pH}, \mathrm{P}$ and $\mathrm{C}: \mathrm{N}$ ratio, while $\mathrm{Al}^{3+}$ was lower.

Amoah-Antwi et al. (2020) showed that, usually, biochar increases soil pH and can increase $\mathrm{Ca}^{2+}$ and $\mathrm{Na}^{+}$availability and reduce the solubility of metals, including Al, as also found by Gul et al. (2015). Pandian et al. (2016) demonstrate that the soil $\mathrm{pH}$ increase is due to alkaline $\mathrm{pH}$ from the biochar (here, $\mathrm{CH}=10.31$ and $\mathrm{CG}=9.65$ ). Biochar $\mathrm{pH}$ is linked both to pyrolysis temperature and feedstock, as wood-based biochar tends to have higher $\mathrm{pH}$ than from crop waste and manure (Gul et al. 2015). According to Tomczyk et al. (2020), higher $\mathrm{pH}$ with increasing temperature has been associated with increases in ash content and oxygen functional groups that occur during pyrolysis. As the two types of biochar $(\mathrm{CH}$ and $\mathrm{CG})$ were produced in high pyrolysis temperature $\left(>500^{\circ} \mathrm{C}\right)$, the resulting alkaline $\mathrm{pH}$ promoted a decrease in soil acidity, when compared to the control (Table 2). The high $\mathrm{pH}$ of biochar is explained by the varying concentrations of alkaline ash in its composition, which are added to the soil as oxides of $\mathrm{Ca}, \mathrm{Mg}, \mathrm{K}$, hydroxides and carbonates (Han et al. 2020).

Here, the applied biochar increased the main cations and nutrients $\left(\mathrm{Ca}^{+2}, \mathrm{~K}^{+}, \mathrm{Na}^{+}, \mathrm{C}, \mathrm{N}, \mathrm{P}\right)$ and their $\mathrm{N}$ content was reduced, as found in previous reports (Lima et al. 2018; Martins Filho et al. 2020) ${ }^{5}$. A point to consider is that, while both $\mathrm{CG}$ and $\mathrm{CH}$ are coffee by-products, both are obtained from different coffee processing stages. While CG has already been used for actual coffee preparation and thus submitted to water extraction, this is not the case for $\mathrm{CH}$. It is likely that the water extraction during coffee preparation for CG biochar reduced nutrient availability in comparison to that from $\mathrm{CH}$ biochar. For example, $\mathrm{CH}$ biochar at $8 \mathrm{t} \cdot \mathrm{ha}^{-1}$ increased $\mathrm{P}$ (2.1 times) and $\mathrm{K}^{+}$(7.9 times) compared to the control. The biochar effect on P availability has been previously reported (El-Eyuoon and Amin 2020).

Coffee husk biochar at $4 \mathrm{t} \cdot \mathrm{ha}^{-1}$ increased $\mathrm{C}$ content by $67 \%$ compared to the control, reinforcing the understanding that biochar is a $\mathrm{C}$ rich product that contains aromatic compounds, representing an excellent alternative for $\mathrm{C}$ sequestration in agriculture soils (Sohi et al. 2010; Zimmerman et al. 2011).

Lima et al. (2018) stated that $\mathrm{CH}$ biochar at $16 \mathrm{t}^{-h^{-1}}{ }^{-1}$ was the treatment that sequestered most $\mathrm{C}$ in the soil and that it is an effective alternative for $\mathrm{C}$ sequestration in agricultural systems as a consequence of the higher stability of $\mathrm{C}$ compounds in biochar compared to other organic waste compounds, as also found with biochar in an alkaline soil from a semi-arid region (El-Eyuoon and Amin 2020).

The CG biochar at $8 \mathrm{t}^{\mathrm{tha}} \mathrm{a}^{-1}$ increased the soil C:N ratio (3.5 times), which was also found to limit $\mathrm{N}$ availability and to change the soil dissolved organic $\mathrm{C}$ and $\mathrm{N}$ substrates and soil microbial community composition and gene abundance in other research (Van Zwieten et al. 2014). The underlying mechanisms for these effects might vary with biochar feedstocks (Lima et al. 2018).

\section{Soil microbial biomass ( $C, N$ and $P$ ), basal respiration and microbial quotient}

Microbial biomass carbon for $\mathrm{CH}$ at 4 thha ${ }^{-1}$ was $210 \%$ higher than for the control soil (Table 3), likely due to the higher labile $C$ and soil organic matter and nutrient availability (Zhou et al. 2017), even for a short time scale, because biochar reportedly provides a suitable habitat for microbial growth (Khadem and Raiesi 2017). This is considered to be due to biochar pores protecting microbes from predators and to $\mathrm{C}$ organic matter and nutrients supplying the substrate necessary for their proper development (Wang et al. 2017).

However, MBC was significantly higher for soils receiving $\mathrm{CH}$ biochar than $\mathrm{CG}$ at all doses, which might be due to its higher specific surface (Lima et al. 2018). The type of waste, pyrolysis temperature, type and soil conditions are variable, which have been shown to influence MBC increments (Zhou et al. 2017).

5. Martins Filho, A. P., Medeiros, E. V., Lima, J. R. S. L., Duda, G. P., Silva, W. M., Antonino, A. C. D., Silva, J. S. A. S., Oliveira, J. B. and Hammecker, C. (2021) Impact of coffee biochar on carbon, microbial biomass and enzyme activities of a sandy soil cultivated with bean. Anais da Academia Brasileira de Ciências. In press. 
Even the lower dose of $\mathrm{CH}$ biochar $\left(4 \mathrm{t} \cdot \mathrm{ha}^{-1}\right)$ increased $\mathrm{MBC}$ and the C:N ratio, but Nmic was not influenced by any treatments. Some studies have reported similar variations on microbial biomass that can be explained by the soil type, biochar feed material and biochar doses (Zheng et al. 2016; Medeiros et al., 2021). Here, sandy soils were used, as did Yadav et al. (2019), who reported an increase in C:N ratio and microbial biomass at the highest doses used, with increases in the $\mathrm{N}$ mineralization process due to the high demand of this nutrient for microbial growth.

The Nmic did not change after incorporating the biochar into the soil. As biochar application does not increase the total nitrogen content of the soil (Table 1), microorganisms were unable to immobilize nitrogen in their biomass. This corroborates the study by Dempster et al. (2012), who evaluated the influence of incorporating biochar on the microbial activity of sandy soils.

Table 3. Carbon microbial biomass, Nmic, Pmic, SBR and $q \mathrm{CO}_{2}$, total abundance of bacteria (16S rRNA gene), fungi (18S rRNA gene) and diazotrophs (nifH gene) in a sandy soil that received different doses of biochar from CG and CH, cultivated with maize.

\begin{tabular}{|c|c|c|c|c|c|c|c|}
\hline & \multicolumn{5}{|c|}{$\operatorname{MBC}\left(\boldsymbol{\mu g} \cdot \mathbf{g}^{-1} \cdot \text { soil) }\right)^{(1)}$} & \multirow[b]{2}{*}{ Model $^{(4)}$} & \multirow[b]{2}{*}{$\mathbf{R}^{2}$} \\
\hline & $4 \mathrm{t} \cdot \mathrm{ha}^{-1}$ & $8 \mathrm{t} \cdot \mathrm{ha}^{-1}$ & $16 \mathrm{t} \cdot \mathrm{ha}^{-1}$ & Mean & & & \\
\hline CG & 82.02 & 83.86 & 76.57 & 80.82 & b & $f(x)=80.82$ & ns \\
\hline $\mathrm{CH}$ & $153.10^{(2)}$ & 122.13 & 122.15 & 132.46 & a & $f(x)=132.46$ & ns \\
\hline Mean & 117.56 & 103.00 & 99.36 & 106.64 & (3) & & \\
\hline \multirow[t]{3}{*}{ Control } & & & & 72.73 & & & \\
\hline & \multicolumn{5}{|c|}{$N_{\text {mic }}\left(\mu g \cdot g^{-1} \cdot\right.$ soil $)$} & & \\
\hline & $4 t \cdot h a^{-1}$ & $8 \mathrm{t} \cdot \mathrm{ha}^{-1}$ & $16 \mathrm{t} \cdot \mathrm{ha}^{-1}$ & Mean & & Model & $\mathbf{R}^{2}$ \\
\hline CG & 41.01 & 16.57 & 26.29 & 27.96 & a & $f(x)=27.96$ & ns \\
\hline $\mathrm{CH}$ & 33.91 & 69.06 & 38.75 & 47.24 & $a$ & $f(x)=47.24$ & ns \\
\hline Mean & 37.46 & 42.82 & 32.52 & 37.60 & & & \\
\hline \multirow[t]{3}{*}{ Control } & & & & 48.78 & & & \\
\hline & \multicolumn{5}{|c|}{$P_{\text {mic }}\left(\mu \mathrm{g} \cdot \mathrm{g}^{-1} \cdot\right.$ soil $)$} & & \\
\hline & $4 \mathrm{t} \cdot h \mathrm{a}^{-1}$ & $8 \mathrm{t} \cdot \mathrm{ha}^{-1}$ & $16 \mathrm{t} \cdot \mathrm{ha}^{-1}$ & Mean & & Model & $\mathbf{R}^{2}$ \\
\hline CG & 0.97 & 2.94 & 2.21 & 2.04 & a & $f(x)=2.04$ & ns \\
\hline $\mathrm{CH}$ & 1.60 & $0.62^{(4)}$ & 2.13 & 1.45 & $a$ & $f(x)=1.45$ & ns \\
\hline Mean & 1.29 & 1.78 & 2.17 & 1.75 & & & \\
\hline \multirow[t]{3}{*}{ Control } & & & & 2.96 & & & \\
\hline & \multicolumn{5}{|c|}{$\mathrm{SBR}\left(\mathrm{mg} \cdot \mathrm{C}-\mathrm{CO}_{2} \cdot \mathrm{kg}^{-1} \cdot \mathrm{day}^{-1}\right)$} & & \\
\hline & 4 t $\cdot \mathrm{ha}^{-1}$ & $8 \mathrm{t} \cdot \mathrm{ha}^{-1}$ & $16 \mathrm{t} \cdot \mathrm{ha}^{-1}$ & Mean & & Model & $\mathbf{R}^{2}$ \\
\hline CG & 31.00 & 34.27 & 28.96 & 31.41 & a & $f(x)=31.41$ & ns \\
\hline $\mathrm{CH}$ & 26.91 & 28.96 & 24.88 & 26.92 & $b$ & $f(x)=26.92$ & ns \\
\hline Mean & 28.96 & 31.62 & 26.92 & 29.16 & & & \\
\hline \multirow[t]{3}{*}{ Control } & & & & 26.53 & & & \\
\hline & \multicolumn{5}{|c|}{$\mathrm{qCO}_{2}\left(\mathrm{mg} \cdot \mathrm{C}-\mathrm{CO}_{2} \cdot \mathrm{g}^{-1} \cdot \mathrm{Cmic} \cdot\right.$ day $\left.^{-1}\right)$} & & \\
\hline & $4 \mathrm{t} \cdot h \mathrm{a}^{-1}$ & $8 \mathrm{t} \cdot h a^{-1}$ & $16 \mathrm{t} \cdot \mathrm{ha}^{-1}$ & Mean & & Model & $\mathbf{R}^{2}$ \\
\hline CG & 39.01 & 41.48 & 38.05 & 39.51 & a & $f(x)=39.51$ & ns \\
\hline $\mathrm{CH}$ & 17.91 & 27.49 & 20.33 & 21.91 & $\mathrm{~b}$ & $f(x)=21.91$ & ns \\
\hline Mean & 28.46 & 34.48 & 29.19 & 30.71 & & & \\
\hline \multirow[t]{3}{*}{ Control } & & & & 52.45 & & & \\
\hline & \multicolumn{5}{|c|}{ Log of 16S rDNA gene copy numbers } & & \\
\hline & $4 \mathrm{t} \cdot \mathrm{ha}^{-1}$ & $8 \mathrm{t} \cdot \mathrm{ha}^{-1}$ & $16 \mathrm{t} \cdot \mathrm{ha}^{-1}$ & Mean & & Model & $\mathbf{R}^{2}$ \\
\hline CG & 8.18 & 9.08 & 9.28 & 8.85 & a & $f(x)=8.85$ & ns \\
\hline $\mathrm{CH}$ & 9.31 & 8.48 & 8.42 & 8.74 & $\mathrm{a}$ & $f(x)=8.74$ & ns \\
\hline Mean & 8.74 & 8.78 & 8.85 & 8.79 & & & \\
\hline Control & & & & 8.34 & & & \\
\hline
\end{tabular}


Table 3. Continuation...

\begin{tabular}{|c|c|c|c|c|c|c|c|c|c|c|}
\hline & \multicolumn{8}{|c|}{ Log of 18S rDNA gene copy numbers } & \multirow[b]{2}{*}{ Model } & \multirow[b]{2}{*}{$\mathbf{R}^{2}$} \\
\hline & $4 \mathrm{t} \cdot \mathrm{ha}^{-1}$ & & $8 \mathrm{t} \cdot \mathrm{ha}^{-1}$ & & $16 \mathrm{t} \cdot \mathrm{ha}^{-1}$ & & Mean & & & \\
\hline CG & 6.05 & $\mathrm{aB}$ & 6.52 & $\mathrm{aAB}$ & 6.87 & $\mathrm{aA}$ & 6.48 & & $f(x)=0.065 x+5.875$ & 0.93 \\
\hline $\mathrm{CH}$ & 6.58 & a & 6.68 & a & 6.18 & $\mathrm{~b}$ & 6.48 & & $f(x)=6.48$ & ns \\
\hline Mean & 6.32 & & 6.60 & & 6.53 & & 6.48 & & & \\
\hline \multirow[t]{3}{*}{ Control } & & & & & & & 6.20 & & & \\
\hline & \multicolumn{8}{|c|}{ Log of nifH gene copy numbers } & & \\
\hline & $4 t \cdot h a^{-1}$ & & $8 \mathrm{t} \cdot \mathrm{ha}^{-1}$ & & $16 \mathrm{t} \cdot \mathrm{ha}^{-1}$ & & Mean & & Model & $\mathbf{R}^{2}$ \\
\hline CG & 4.41 & B & 4.76 & A & 4.73 & $A B$ & 4.63 & a & $f(x)=0.065 x+5.875$ & 0.93 \\
\hline $\mathrm{CH}$ & 4.46 & & 4.40 & & 4.22 & & 4.36 & $b$ & $f(x)=6.48$ & ns \\
\hline Mean & 4.43 & & 4.58 & & 4.47 & & 4.50 & & & \\
\hline Control & & & & & & & 4.62 & & & \\
\hline
\end{tabular}

(1) The analysis of variance was performed at the $5 \%$ significance level, where the absence of letters indicates that there were no significant differences (ns). Means followed by different lowercase letters between columns and uppercase letters between lines differed, using the Tukey's test at the $5 \%$ level of significance. (2) The means in bold differed from the control according to the Dunnett test at the level of $5 \%$ of significance.

(3) Overall mean in bold differed from the control according to the Helmet's contrast at the $5 \%$ significance.

(4) Regression analysis was performed for the quantitative variables (increasing doses of the biochar) with different variances and the corresponding linear model $[f(x)]$ was shown for each biochar, followed by the adjusted $\mathrm{R}^{2}$. In the case of data with equal variances (ns), the means were considered similar and the global mean (constant) was calculated.

The Pmic presented the lowest value with the addition of the $8 \mathrm{t} \cdot \mathrm{ha}^{-1}$ dose of CG compared to the control (Table 2). At this same dose, the available $\mathrm{P}$ was significantly higher, demonstrating that the microbial biomass was able to mineralize the $\mathrm{P}$ from the biochar and make it available in the soil. Thus, the phosphorus from the biomass is released in the soil, making it available to the plants. The increase in Pmic can be related to the properties of the biochar, which, after being incorporated into the soil, improved the environment for colonization by microorganisms (Zhai et al. 2015). However, the current maize experiment showed an increase in the available $P$ content, with $P$ from microbial biomass reduced by biochar. These microbial biomass variations can be explained by the type of soil used in the experiment and by the type and rate of application of the biochar (Zhang et al. 2014; Zhu et al. 2017).

Castaldi et al (2011) found that biochar incorporation facilitates C, N and P mineralization, which is affected by biochar particle size, since thin particles are mineralized faster than thicker ones. Another factor is the feedstock lignin and complex compounds content, since the higher these are, the slower the mineralization tends to be, which might explain the observed differences between the $\mathrm{CH}$ and $\mathrm{CG}$ biochar.

The CG biochar at $8 \mathrm{t} \cdot \mathrm{ha}^{-1}$, although there is no significant difference, numerically increased the SBR rate by $30 \%$ compared to the control. Lima et al. (2018) have shown that this increase in $\mathrm{C}-\mathrm{CO}_{2}$ fluxes varies according to the feedstock used, porosity and specific surface area.

\section{Soil microbial abundance}

The abundance of total bacteria, gene $16 \mathrm{~S}$ rRNA, showed no statistical difference between the number of copies found in the treatments and the biochar doses compared to the control and soil with manure. With respect to the fungi community represented by the $18 \mathrm{~S}$ rRNA gene, in the soil that received the manure treatment, the number of copies of the gene was lower than the number of copies found in the absolute control. The highest dose of biochars $\left(16 \mathrm{t} \cdot \mathrm{ha}^{-1}\right)$ influenced the abundance of $18 \mathrm{~S}$ genes, with $\mathrm{CH}$ being higher than CG. The results showed that all doses of CG differed statistically from the control for the population of diazotrophs, with a lower number of copies of the gene in question in soils treated with CG. Besides, the highest doses of both biochars differed, with soils treated with $\mathrm{CH}$ having a higher number of copies of the respective gene compared to CG (Table 3 ).

Coffee ground biochar at $16 \mathrm{t} \cdot \mathrm{ha}^{-1}$ showed a trend toward higher microbial levels, though not significant, with respect to the abundance of bacteria, fungi and diazotrophic genes (increase of 11,10 and $2 \%$, respectively), likely due to the supply of degradable carbon (Manirakiza et al. 2019). Biochar influences soil microbial abundance by interfering with the chemical and physical properties of the soil and can provide a habitat for microbial growth (Khadem and Raiesi 2017) due to the structures of its pores, protecting microbes from the action of predators. 


\section{Multivariate analysis}

On the CAP coordinates plot (Fig. 1), the PC1 and PC2 axis explained 35 and 16\% of the variation of bacterial community; 40 and $20 \%$ of fungal community and 30 and $23 \%$ of diazotrophic community numbers, respectively. The analysis revealed a similar microbial composition for each biochar type, independent of dose since the plots separated the communities according to biochar type.

Principal coordinates canonical analysis explained $51 \%$ of the total variation and correlated to the DGGE distance matrix for the $16 \mathrm{~S}$ rRNA gene (Fig. 1a). The lower doses of $\mathrm{CH}$ were positively correlated with copy numbers of $16 \mathrm{~S}$ rRNA, $18 \mathrm{~S}$ rRNA, nifH, Pmic, $q \mathrm{CO}_{2}$ and Nmic, while $\mathrm{CG}$ showed influence on $\mathrm{Ca}^{+2}, \mathrm{Na}^{+}, \mathrm{Al}^{+3}$ and $\mathrm{SBR}$. These variables were negatively correlated with copy numbers for the $16 \mathrm{~S}$ rRNA gene. The impact of biochar on increased microbial abundance has been documented in both pot and field experiments (Jones et al. 2012, Chen et al. 2016; Liu et al. 2019).

Biochar amendments serve as a habitat and protection for microorganisms against predator's action. Here, bacterial abundance genes were grouped according to biochar types and doses, demonstrating that biochar can be considered a consumable carbon source that changes according to feedstock (Chen et al. 2016). Bacterial abundance was largely related to the increase in soil organic matter and soil pH, as also shown by Liu et al. (2019).
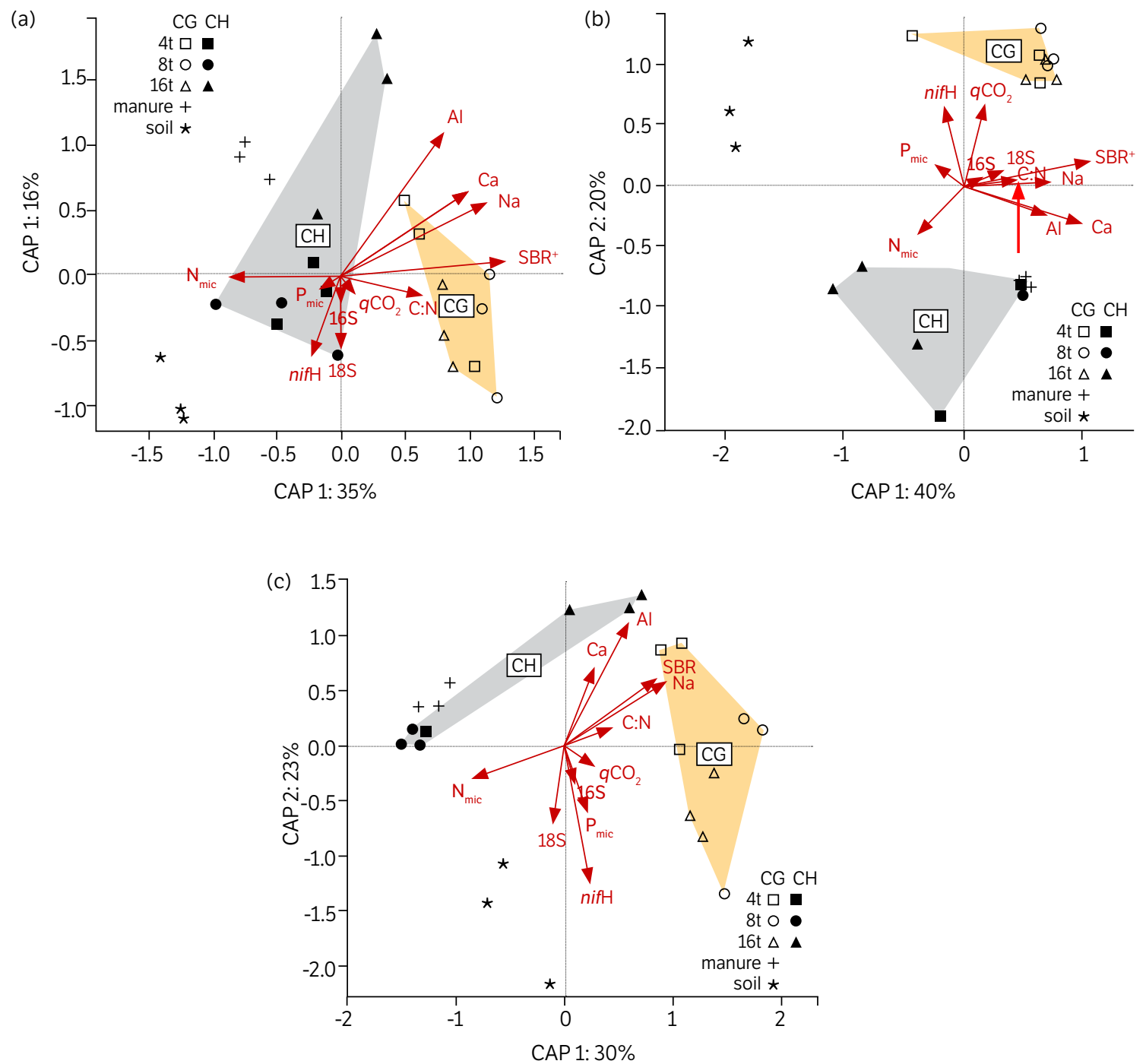

Figure 1. Canonical analysis of principal coordinates between structures of a) bacterial, b) fungal and c) diazotrophic communities and the attributes of a sandy soil that received different doses of biochar from CG and $\mathrm{CH}$, cultivated with maize.

$\mathrm{CG}=$ coffee ground; $\mathrm{CH}=$ coffee husk; $\mathrm{MBC}=$ microbial biomass carbon; $\mathrm{Nmic}=$ microbial biomass $\mathrm{N} ; \mathrm{Pmic}=$ microbial biomass P; $\mathrm{SBR}=$ soil basal respiration; $\mathrm{qCO}_{2}=$ metabolic quotient. 
Soil fungal communities from CH and CG biochar-treated soil were distanced from each other, with few overlaps, and from the control treatment. Fungal communities are next to the Nmic at $16 \mathrm{t} \cdot \mathrm{ha}^{-1} \mathrm{of} \mathrm{CH}$. All CG doses were more favorable to the $18 \mathrm{~S}$ rRNA gene copy number, correlating positively with SBR.

While some studies reported that the fungal community was not affected and no change in the community structure with biochar application (Chen et al. 2016), Jones et al. (2012) found a possible inhibition effect on fungal growth and Chen et al. (2013) reported that fungal communities experienced structural changes with increased diversity. In the current study, CG biochar led to a slight increase in the abundance of fungi by only $10 \%$ at the higher dose. This can be attributed to the product porosity and raw composition used in the biochar production, since the fungi have the capacity to degrade more recalcitrant materials (Gul et al. 2015).

The canonical analysis explained 53\% of the total variation for the nifH gene (Fig. 1c). The highest CG dose approached the nifH copy numbers, Pmic, $q \mathrm{CO}_{2}$ and $16 \mathrm{~S}$ rRNA gene and the lower doses approached the C:N ratio, $\mathrm{Na}^{+}$and SBR. Lehmann et al. (2011) demonstrated that bacteria respond more rapidly to $\mathrm{pH}$ changes, while fungi tolerate a broad $\mathrm{pH}$ range and are not as affected by the modifications that biochar exerts on the soil. Thus, the $\mathrm{pH}$ of the biochar can exert influence on the soil microbial communities' abundance, confirming these findings. Soil with CG biochar with its lower $\mathrm{pH}$ increased diazotrophs abundance, while $\mathrm{CH}$ biochar with its higher $\mathrm{pH}$ decreased this community with increase the dose. The increased diazotroph abundance obtained with CG biochar was likely due to its $\mathrm{pH}$ (5.27) being close to the optimal (5.5-6.0) range for biological nitrogen fixation, also resulting in increased nutrient availability and labile organic $\mathrm{C}$ that can be directly utilized by soil diazotrophs community (Liu et al. 2019).

\section{Correlation heatmap analysis}

The correlation heatmap analysis (Fig. 2) revealed significant linear correlations ( $\mathrm{p} \leq 0.05)$ among the variables, mainly the positive ones between TOC and the largest number of variables, including $\mathrm{C}, \mathrm{P}, \mathrm{pH}, \mathrm{H}+\mathrm{Al}, \mathrm{Mg}^{2+}, \mathrm{Ca}^{2+}, \mathrm{SBR}$, $\mathrm{Al}^{3+}$ and $\mathrm{Na}^{+}$.

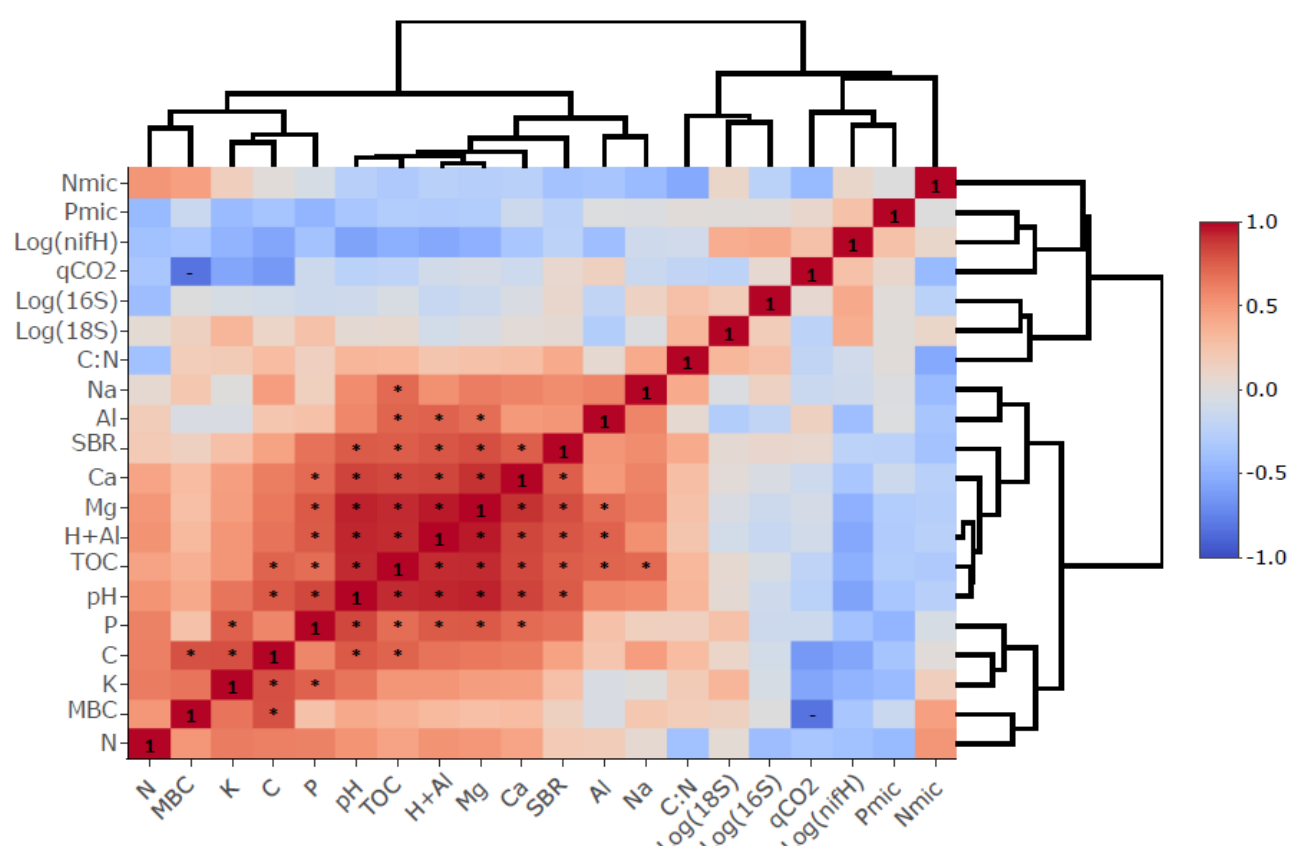

Figure 2. Heatmap correlations between variables of sandy soil that received different doses of biochar from $\mathrm{CG}$ and $\mathrm{CH}$, cultivated with maize. $\mathrm{MBC}=$ microbial biomass carbon; $\mathrm{Nmic}=$ microbial biomass $\mathrm{N}$; Pmic = microbial biomass P; $\mathrm{SBR}=$ soil basal respiration; $q \mathrm{CO}_{2}=$ metabolic quotient, $\mathrm{Log}(16 \mathrm{~S})=$ Log of $16 S$ rRNA gene copy numbers; Log(18S) $=$ Log of $18 S$ rRNA gene copy numbers; $\log ($ nifH $)=\log$ of nifH gene copy numbers. The polygons with asterisks $\left(^{\star}\right)$ and dashes $(-)$ show, respectively, significant positive and negative correlations $(<0.05)$ with modules greater than 0.7 , according to statistics based on Pearson's product-moment correlation coefficient $(r)$ following the t distribution. 
Increased C content in sandy soils due to coffee biochar was accompanied by an increase in MBC. Use of residues rich in organic matter has been a widely used practice worldwide, due to its large-scale availability and nutrient content. The stabilized part of the $\mathrm{C}$ found in the soil is quite susceptible to microbial decomposition and through a possible combination of physical protection and chemical complexation, the stable carbon may have been protected against decomposition (Martins Filho et al. 2020).

This study showed positive effects from the reuse of coffee waste to produce biochar as an eco-friendly and low-cost alternative to increase sandy soil quality by different plausible mechanisms. Here, the $\mathrm{CH}$ biochar was the most efficient in increasing the chemical and microbiological attributes of sandy soil. A previous study using both coffee biochar $(\mathrm{CH}$ and CG), Lima et al. (2018) showed that CH biochar presented a high specific surface area that contributed to a higher water holding capacity on the wet end of the retention curve, compared to CG.

The addition of biochar from coffee waste to acid soils improve soil quality and plant growth due to its alkalinity and high $\mathrm{pH}$ buffering capacity. A shift in $\mathrm{pH}$ and reduction in $\mathrm{Al}$ caused by biochar amendments will improve the availability of $\mathrm{P}, \mathrm{Ca}$ and $\mathrm{Mg}$, resulting in a balanced nutrient supply in the rhizosphere, thus enhancing the productivity of cultivated plants (Yu et al. 2019).

This study demonstrated that soil nutrients and microbial biomass increased in response to the type and doses of biochar. Thus, the reuse of coffee residues (mainly husk) for biochar production is recommended to increase sandy soil quality in Brazilian semi-arid areas, which is plausible due to the large amount of waste that the coffee industry produces. Harnessing such waste for field experiments can be an eco-friendly alternative to improve soil health. However, additional research is necessary to investigate some of those variables where no clear significant differences were observed in order to better understand the potential benefits and underlying mechanisms from biochar amendment applications in different culture cycles and in different crops.

\section{CONCLUSION}

The present study provided an insight into the effects of biochar produced from coffee waste as a low-cost alternative to promote sandy soil quality. This strategy can help small farmers to improve their productivity due the numerous benefits provided by biochar to improve soil health and the environment, as well as to its ability to sequester carbon in the soil. Here, the treatments that received different biochar types and doses considerably altered the soil quality. Application of lower doses of $\mathrm{CH}$ biochar increased the $\mathrm{C}$ content, $\mathrm{MBC}$ and $\mathrm{Nmic}$ (3, 2.1 and 1.6 times, respectively). Application of higher doses of CG biochar showed a slight increase in the abundance of bacteria, fungi and diazotrophic genes (increase of 11, 10 and $2 \%$, respectively). However, this pot experiment only lasted for one crop season, therefore further study is needed to focus on the field and long-term impacts of biochar soil applications. Despite this, a positive effect from the reuse of coffee waste to produce biochar as an eco-friendly and low-cost alternative to increase sandy soil quality was found.

\section{AUTHORS' CONTRIBUTION}

Conceptualization: Lima J. R. S., Medeiros E. V. and Hammecker C.; Methodology: Medeiros E. V., Lima J. R. S., Fracetto G. G. M., Fracetto F. J. C. and Duda G. P.; Investigation: Silva C. C. G., Martins Filho A. P. and Costa D. P.; Writing - Original Draft: Medeiros E. V., Costa D. P., Silva C. C. G. and Lira Junior M. A.; Writing - Review and Editing: Medeiros E.V., Costa D. P., Silva C. C. G. and Lira Junior M. A.; Funding Acquisition: Medeiros E. V. and Lima J. R. S.; Resources: Fracetto G. G. M., Fracetto F. J. C., Duda G. P., Silva C. C. G. and Martins Filho, A. P.; Supervision: Medeiros E. V., Hammecker C. and Lima J. R. S.

\section{DATA AVAILABILITY STATEMENT}

Data will be available when requested. 


\section{FUNDING}

Conselho Nacional de Desenvolvimento Científico e Tecnológico

[https://doi.org/10.13039/501100003593]

Grants No. 313174/2018-0 and 426497/2018-0

Coordenação de Aperfeiçoamento de Pessoal de Nível Superior

[https://doi.org/10.13039/501100002322]

Finance Code 001

\section{ACKNOWLEDGMENTS}

This study was supported by the Conselho Nacional de Desenvolvimento Científico e Tecnológico and Coordenação de Aperfeiçoamento de Pessoal de Nível Superior. Finally, we thank the anonymous reviewers for help and comments that have contributed to improvement of the manuscript.

\section{REFERENCES}

Alef, K. and Nannipieri, P. (1995). Methods in Applied Soil Microbiology and Biochemistry. San Diego: Academic Press.

Amoah-Antwi, C., Kwiatkowska-Malina, J., Thornton, S. F., Fenton, O., Malina, G. and Szara, E. (2020). Restoration of soil quality using biochar and brown coal waste: A review. Science of The Total Environment, 722, 137852.

Anderson, I. C., Campebell, C. D. and Prosser, J. I. (2003). Potential bias of fungal 18S rDNA and internal transcribed spacer polymerase chain reaction primers for estimating fungal biodiversity in soil. Environmental Microbiology, 5, 36-47. https://doi. org/10.1046/j.1462-2920.2003.00383.x

Anderson, T.-H. and Domsch, K. H. (1993). The metabolic quotient for $\mathrm{CO}_{2}\left(q \mathrm{CO}_{2}\right)$ as a specific activity parameter to assess the effects of environmental conditions, such as pH, on the microbial biomass of forest soils. Soil Biology and Biochemistry, 25, 393-395. https:// doi.org/10.1016/0038-0717(93)90140-7

Barros, J. A., Medeiros, E. V., Costa, D. P., Duda, G. P., Lima, J. R. S., Santos, U. J., Antonino, A. C. D. and Hammecker, C. (2019). Human disturbance affects enzyme activity, microbial biomass and organic carbon in tropical dry sub-humid pasture and forest soils. Archives of Agronomy and Soil Science, 66, 458-472. https://doi.org/10.1080/03650340.2019.1622095

Castaldi, S., Riondino, M., Baronti, S., Esposito, F. R., Marzaioli, R., Rutigliano, F. A. and Miglietta, F. (2011). Impact of biochar application to a Mediterranean wheat crop on soil microbial activity and greenhouse gas fluxes. Chemosphere, 85, 1464-1471. https://doi.org/10.1016/j. chemosphere.2011.08.031

Cavalcanti, F. J. A. (2008). Recomendação de adubação para o Estado de Pernambuco: segunda aproximação. Recife: IPA.

Chen, J., Liu, X., Zheng, J., Zhang, B., Lu, H., Chi, Z., Pan, G., Li, L., Zheng, J., Zhang, X., Wang, J. and Yu, X (2013). Biochar soil amendment increased bacterial but decreased fungal gene abundance with shifts in community structure in a slightly acid rice paddy from Southwest China. Applied Soil Ecology, 71, 33-44. https://doi.org/10.1016/j.apsoil.2013.05.003

Chen, J., Sun, X., Li, L., Liu, X., Zhang, B., Zheng, J. and Pan, G. (2016). Change in active microbial community structure, abundance and carbon cycling in an acid rice paddy soil with the addition of biochar. European Journal of Soil Science, 67, 857-867. https://doi. org/10.1111/ejss.12388 
Dempster, D. N., Gleeson, D. B., Solaiman, Z. M., Jones, D. L. and Murphy, D. V. (2012). Decreased soil microbial biomass and nitrogen mineralisation with Eucalyptus biochar addition to a coarse textured soil. Plant and Soil, 354, 311-324. https://doi.org/10.1007/ s11104-011-1067-5

El-Eyuoon, A. and Amin, A. Z. (2020). Carbon sequestration, kinetics of ammonia volatilization and nutrient availability in alkaline sandy soil as a function on applying calotropis biochar produced at different pyrolysis temperatures. Science of The Total Environment, 726 , 138489. https://doi.org/10.1016/j.scitotenv.2020.138489

Fierer, N., Jackson, J. A., Vilgalys, R. and Jackson, R. B. (2005). Assessment of Soil Microbial Community Structure by Use of TaxonSpecific Quantitative PCR Assa. Applied and Environment Microbiology, 71, 4117-4120. https://doi.org/10.1128/AEM.71.7.4117-4120.2005

Gardes, M. and Bruns, T. D. (1993). ITS primers with enhanced specificity for basidiomycetes application to the identification of mycorrhizae and rusts. Molecular Ecology, 2, 113-118. https://doi.org/10.1111/j.1365-294x.1993.tb00005.x

Gul, S., Whalen, J. K., Thomas, B. W., Sachdeva, V. and Deng, H. (2015). Physico-chemical properties and microbial responses in biocharamended soils: Mechanisms and future directions. Agriculture, Ecosystems and Environment, 206, 46-59 https://doi.org/10.1016/j. agee.2015.03.015

Han, L., Sun, K., Yang, Y., Xia, X., Li, F., Yang, Z. and Xing, B. (2020). Biochar's stability and effect on the content, composition and turnover of soil organic carbon. Geoderma 364, 114184. https://doi.org/10.1016/j.geoderma.2020.114184

Jones, D. L., Rousk, J., Edwards-Jones, G., DeLuca, T. H. and Murphy, D. V. (2012). Biochar-mediated changes in soil quality and plant growth in a three year field trial. Soil Biology and Biochemistry, 45, 113-124. https://doi.org/10.1016/j.soilbio.2011.10.012

Khadem, A. and Raiesi, F. (2017). Responses of microbial performance and community to corn biochar in calcareous sandy and clayey soils. Applied Soil Ecology, 114, 16-27. https://doi.org/10.1016/j.apsoil.2017.02.018

Lehmann, J., Rillig, M. C., Thies, J., Masiello, C. A., Hockaday, W. C. and Crowley, D. (2011). Biochar effects on soil biota - A review. Soil Biology and Biochemistry, 43, 1812-1836. https://doi.org/10.1016/j.soilbio.2011.04.022

Lima, J. R. S., Silva, W. M., Medeiros, E. V., Duda, G. P., Corrêa, M. M., Martins Filho, A. P., Clermont-Dauphin, C., Antonino, A. C. D. and Hammecker, C. (2018). Effect of biochar on physicochemical properties of a sandy soil and maize growth in a greenhouse experiment. Geoderma. 319, 14-23. https://doi.org/10.1016/j.geoderma.2017.12.033

Liu, X., Liu, C., Gao, W., Xue, C., Guo, Z., Jiang, L., Li, F. and Liu, Y. (2019). Impact of biochar amendment on the abundance and structure of diazotrophic community in an alkaline soil. Science of The Total Environment, 688, 944-951. https://doi.org/10.1016/j.scitotenv.2019.06.293

Liu, Y., Zhu, J., Ye, C., Zhu, P., Ba, Q., Pang, J. and Shu, L. (2018). Effects of biochar application on the abundance and community composition of denitrifying bacteria in a reclaimed soil from coal mining subsidence area. Science of the Total Environment, 625, 12181224. https://doi.org/10.1016/j.scitotenv.2018.01.003

Manirakiza, E., Ziadi, N., Luce, M.S., Hamel, C., Antoun, H. and Karam, A. (2019). Nitrogen mineralization and microbial biomass carbon and nitrogen in response to co-application of biochar and paper mill biosolids. Applied Soil Ecology, 142, 90-98. https://doi.org/10.1016/j. apsoil.2019.04.025

Martinez, C. L. M., Sermyagina, E., Carneiro, A. C. O., Vakkilainen, E. and Cardoso, M. (2019). Production and characterization of coffeepine wood residue briquettes as an alternative fuel for local firing systems in Brazil. Biomass and Bioenergy. 123, 70-77. https://doi. org/10.1016/j.biombioe.2019.02.013

Medeiros, E. V., Lima, N. T., Lima, J. R. S., Pinto, K. M. S., Costa, D. P., Franco Junior, C. L. and Hammecker, C. (2021). Biochar as a strategy to manage plant diseases caused by pathogens inhabiting the soil: a critical review. Phytoparasitica, 1-14. https://doi.org/10.1007/ s12600-021-00887-y

Mendonça, E. S. and Matos, E. S. (2017). Matéria Orgânica do Solo: Métodos de Análises. Viçosa: UFV. 
Muyzer, G., De Waal, E. C. and Uitterlinden, A. G. (1993). Profiling of complex microbial populations by denaturing gradient gel electrophoresis analysis of polymerase chain reaction-amplified genes coding for $16 \mathrm{~S}$ rRNA. Applied and Environmental Microbiology, 59, 695-700. https://doi.org/ 10.1128/AEM.59.3.695-700.1993

Pandian, K., Subramaniayan, P., Gnasekaran, P. and Chitraputhirapillai, S. (2016). Effect of biochar amendment on soil physical, chemical and biological properties and groundnut yield in rainfed Alfisol of semi-arid tropics. Archives of Agronomy and Soil Science, 62, 12931310. http://doi.org/10.1080/03650340.2016.1139086

Poly, F., Monrozier, L. J. and Bally, R. (2001). Improvement in the RFLP procedure for studying the diversity of nifH genes in communities of nitrogen fixers in soil. Research in Microbiology, 152, 95-103. https://doi.org/10.1016/S0923-2508(00)01172-4

Pranagal, J., Oleszczuk, P., Tomaszewska-Krojańska, D., Kraska, P. and Różyło, K. (2017). Effect of biochar application on the physical properties of Haplic Podzol. Soil and Tillage Research, 174, 92-103. https://doi.org/10.1016/j.still.2017.06.007

R Core Team (2020). R: A language and environment for statistical computing. R Foundation for Statistical Computing, Vienna, Austria. [Accessed Oct. 01, 2020]. Available at: https://www.R-project.org//tool/81287/r-a-language-and-environment-for-statistical-computing

Rangabhashiyam, S. and Balasubramanian, P. (2019). The potential of lignocellulosic biomass precursors for biochar production: Performance, mechanism and wastewater application—A review. Industrial Crops and Products, 128, 405-423. https://doi.org/10.1016/j. indcrop.2018.11.041

Silva, F. C. (2009). Manual de análises químicas de solos, plantas e fertilizantes. Brasília: Embrapa.

Simonet, P., Grojean, M. C., Misra, A. K., Nazaret, S., Cournoyer, B. and Normand, P. (1991). Frankia Genus-Specific Characterization by Polymerase Chain Reaction. Appl Environ Microbiol. 57, 3278-3286. https://doi.org/10.1128/AEM.57.11.3278-3286.1991

Singh, C., Tiwari, S., Gupta, V. K. and Singh, J. S. (2018). The effect of rice husk biochar on soil nutrient status, microbial biomass and paddy productivity of nutrient poor agriculture soils. Catena, 171, 485-493. https://doi.org/10.1016/j.catena.2018.07.042

Smit, E., Leeflang, P., Glandorf, B., van Elsas, J. D. and Wernars, K. (1999). Analysis of fungal diversity in the wheat rhizosphere by sequencing of cloned PCR-amplified genes encoding 18S rRNA and temperature gradient gel electrophoresis. Applied Environment Microbiology, 65, 2614-2621. https://doi.org/10.1128/AEM.65.6.2614-2621.1999

Sohi, S.P., Krull, E., Lopez-Capel, E. and Bol, R. (2010). A review of biochar and its use and function in soil. In D. Sparks (Ed.), Advances in Agronomy 105 (p. 47-82). Cambridge: Academic Press.

Tan, Z., Lin, C. S. K., Ji, X. and Rainey, T. J. (2017). Returning biochar to fields: A review. Applied Soil Ecology, 116, 1-11. https://doi. org/10.1016/j.apsoil.2017.03.017

Tomczyk, A., Sokołowska, Z. and Boguta, P. (2020). Biochar physicochemical properties: pyrolysis temperature and feedstock kind effects. Reviews in Environmental Science and Biotechnology, 19, 191-215. https://doi.org/10.1007/s11157-020-09523-3

Tsai, W.-T., Liu, S.-C. and Hsieh, C.-H. (2012). Preparation and fuel properties of biochars from the pyrolysis of exhausted coffee residue. Journal of Analytical and Applied Pyrolysis, 93, 63-67. https://doi.org/10.1016/j.jaap.2011.09.010

Van Zwieten, L., Singh, B. P., Kimber, S. W. L., Murphy, D. V., Macdonald, L. M., Rust, J. and Morris, S. (2014). An incubation study investigating the mechanisms that impact $\mathrm{N} 2 \mathrm{O}$ flux from soil following biochar application. Agriculture, Ecosystems and Environment, 191, 53-62. http://doi.org/10.1016/j.agee.2014.02.030

Wang, H., Zheng, H., Jiang, Z., Dai, Y., Liu, G., Chen, L., Luo, X., Liu, M. and Wang, Z. (2017). Efficacies of biochar and biochar-based amendment on vegetable yield and nitrogen utilization in four consecutive planting seasons. Science of The Total Environment, 593594, 124-133. https://doi.org/10.1016/j.scitotenv.2017.03.096 
White, T. J., Bruns, T., Lee, S. and Taylor, J. (1990). Amplification and direct sequencing of fungal ribosomal RNA genes for phylogenetics. In M. A. Innis, D. H. Gelfand, J. J. Sninsky and T. J. White (Eds.), PCR Protocols: a guide to methods and application (p. 315-322). London: Academic Press.

Yadav, V., Jain, S., Mishra, P., Khare, P., Shukla, A. K., Karak, T. and Singh, A. K. (2019). Amelioration in nutrient mineralization and microbial activities of sandy loam soil by short term field aged biochar. Applied Soil Ecology, 138, 144-155. https://doi.org/10.1016/j.apsoil.2019.01.012 Yeomans, J. C. and Bremner, J. M. (1988). A rapid and precise method for routine determination of organic carbon in soil. Communications in Soil Science and Plant Analysis, 19, 1467-1476. https://doi.org/10.1080/00103628809368027

Yu, H., Zou, W., Chen, J., Chen, H., Yu, Z., Huang, J., Tang, H., Wei, X. and Gao, B. (2019). Biochar amendment improves crop production in problem soils: A review. Journal of Environmental Management, 232, 8-21. https://doi.org/10.1016/j.jenvman.2018.10.117

Zhai, L., Caiji, Z., Liu, J., Wang, H., Ren, T., Gai, X., Xi, B. and Liu, H. (2015). Short-term effects of maize residue biochar on phosphorus availability in two soils with different phosphorus sorption capacities. Biology and Fertility of Soils, 51, 113-122. https://doi.org/10.1007/ s00374-014-0954-3

Zhang, Q.-Z., Dijkstra, F. A., Liu, X.-R., Wang, Y.-D., Huang, J. and Lu, N. (2014). Effects of Biochar on Soil Microbial Biomass after Four Years of Consecutive Application in the North China Plain. PLoS One, 9, e102062. https://doi.org/10.1371/journal.pone.0102062

Zheng, J., Chen, J., Pan, G., Liu, X., Zhang, X., Li, L., Bian, R., Cheng, K., Zheng, J. (2016). Biochar decreased microbial metabolic quotient and shifted community composition four years after a single incorporation in a slightly acid rice paddy from southwest China. Science of the Total Environment, 571, 206-217. https://doi.org/10.1016/j.scitotenv.2016.07.135

Zhou, H., Zhang, D., Wang, P., Liu, X., Cheng, K., Li, L., Zheng, J., Zhang, X., Zheng, J., Crowley, D., van Zwieten, L. and Pan, G. (2017). Changes in microbial biomass and the metabolic quotient with biochar addition to agricultural soils: A Meta-analysis. Agriculture, Ecosystems and Environment, 239, 80-89. https://doi.org/10.1016/j.agee.2017.01.006

Zhu, X., Chen, B., Zhu, L. and Xing, B. (2017). Effects and mechanisms of biochar-microbe interactions in soil improvement and pollution remediation: A review. Environmental Pollution, 277, 98-115. http://doi.org/10.1016/j.envpol.2017.04.032

Zimmerman, A. R., Gao, B. and Ahn, M.-Y. (2011). Positive and negative carbon mineralization priming effects among a variety of biocharamended soils. Soil Biology and Biochemistry, 43, 1169-1179. https://doi.org/10.1016/j.soilbio.2011.02.005 